\title{
Microbial Reduction Potential of Chlorine and its Contribution to Incidence of Stress Response Genes in Antibiotic-Resistant Bacteria
}

\author{
Busayo Mutiat Olowe $^{1^{*}}$ and Olufunke Adelegan ${ }^{2}$ \\ ${ }^{1}$ Department of Biological Sciences, Microbiology Unit, Faculty of Basic Medicals and Applied \\ Sciences, Lead City University, Ibadan, Oyo-State, Nigeria. \\ ${ }^{2}$ Department of Medical Microbiology and Parasitology, Afe Babalola University, Ado-Ekiti, Nigeria.
}

\section{Authors' contributions}

This work was carried out in collaboration between both authors. Author BMO designed the study, performed the experiments, wrote the protocol and wrote the first draft of the manuscript. Authors $O A$ and $B M O$ managed the results of the study. Author $A O$ managed the literature searches. All authors read and approved the final manuscript.

Article Information

DOI: 10.9734/ARRB/2021/v36i430368 Editor(s):

(1) Dr Paola Angelini, University of Perugia, Italy.

Reviewers:

(1) Mr.Someshwar Dattatraya Mankar, Pravara Rural College Of Pharmacy, India.

(2) Alyaa Jabbar Hamid, Al-Furat Al-Awsat Technical University, Iraq Complete Peer review History: http://www.sdiarticle4.com/review-history/67526

Original Research Article

Received 02 February 2021

Accepted 08 April 2021

Published 03 May 2021

ABSTRACT

Background: The quest for potability of drinking water in various homes led to the widely use of chlorine or chlorine compound in treatment of water. Which however has contributed to increasing incidences of antibiotic resistance in the environment.

Aim: This study aimed to investigate the microbial reduction potential and contribution of Sodium hypochlorite, $\mathrm{NaOCl}$, to incidence of stress response genes in antibiotic-resistant bacteria.

Study Design: Experimental Design was adopted in this study

Place and Duration of the Study: The study was carried out at the Department of Microbiology, Faculty of Science, Ekiti State University between October, 2019 and February, 2020.

Methodology: Sixteen (16) different water samples were randomly collected from various homes in Ajilosun, Ado-Ekiti and were chlorinated following manufacturer's instruction. Microbial load of both raw and chlorinated water was determined using standard pour plate technique. Standard streaking method was used to isolate bacteria from chlorinated water samples. Standard CLSI technique was used to test the sensitivity of isolates to different antibiotics and PCR technique was employed to 
detect stress response genes (RpoS, RpoN, KatF genes) in multiple antibiotic-resistant bacterial isolates.

Results: The result showed $24 \%$ and $52 \%$ reduction in the microbial load of well and pipe-borne water samples respectively following treatment with $\mathrm{NaOCl}$ for $180 \mathrm{sec}$. The different identified bacterial isolates recovered from chlorinated water samples included Enterobacter aerogenes (7.14 $\%)$, Proteus vulgaris (10.71\%), Escherichia coli (25\%), Bacillus cereus (32.14 \%), Bacillus licheniformis (14.29\%) and Staphylococcus aureus (10.70\%). The bacterial isolates demonstrated varying resistance pattern to the different antibiotics. RpoS, RpoN and KatF genes encoding stress responses were detected in some of the tested antibiotic-resistant isolates.

Conclusion: The study therefore stresses the importance of chlorination in contributing to increasing incidence of resistance of bacteria to stressors in the environment. Hence, subverting chlorination efficacy in treatment of water.

Keywords: Antibiotic resistance; drinking water; sodium hypochlorite; stress genes; total viable bacterial count.

\section{INTRODUCTION}

The lack of access to potable water, increasingly impaired by the presence of waterborne pathogens, continues to be a major contributor to the disease burden, morbidity, retardation of economic growth and well-being of the populace in many developing countries including Nigeria [1-2]. Due to this global challenge, many homes employ water disinfection strategies to ensure potability of the water available in their homes. Chlorine or chlorine compound becomes an attractive option for disinfection of water in most homes in the developing countries. This is because chlorine is easy to handle, destroys target microorganisms by oxidizing cellular materials, and is more cost-effective than either UV or ozone [3].

In this study, Sodium hypochlorite, $\mathrm{NaOCl}$, with the product name "Water guard" was used as a chlorine compound in investigating its efficacy on reduction of bacterial load of water samples collected from different homes in Ado-Ekiti, Ekiti State, Nigeria. Generally, it has been observed that water guard is widely used in many homes in both urban and sub-urban areas in Ekiti as water disinfectants. Water guard is a greenish yellow liquid that is prepared by reacting dilute caustic soda solution with liquid or gaseous chlorine accompanied by cooling and is used as a disinfectant in water and waste water treatment, swimming pool and sanitary equipment among other uses [4].

Although, the use of chlorination is of benefits for the production of safe drinking water, chlorination may also promote the increase of antibiotic resistance genes (ARG) and free bacterial DNA in the environment [5]. Antibiotic resistance is due to the presence of ARGs in chromosomes and/or in mobile genetic elements such as transposons and plasmids [6]. Antibiotic resistance genes can be spatially or functionally associated with other genetic elements which can cause a positive co-selection of ARGs due to a primary selection of the associated genes [7]. Antibiotic and disinfectant resistance can be associated by sharing of function by coregulation of their genes [8]. On the other hand, ARGs, horizontally transferred in microbial communities, can as well be associated with cross-resistance factor such as efflux mechanisms capable of detoxifying multiple stressors [9].

Studies have reported resistance of antibiotic resistant-bacteria to chlorination [1,10-12]. This may likely be induced by the underlying mechanisms of cross- or co-resistance to disinfectants and antibiotics [11-12]. Hence, the need to continually monitor the occurrences of Antibiotic resistant bacteria in chlorinated water. This study therefore aimed to determine the level of microbial load of different water samples available for domestic use and determine the efficacy of the 'water guard' used in water treatment. Also, the effect of cross- or coresistance to chlorination and antibiotics will be determined by investigation the presence of Stress response genes, such as RpoS, RpoN, KatF which are generally important for bacterial survival during water treatments, in antibiotic resistant bacteria.

\section{MATERIALS AND METHODS}

\subsection{Sampling Site and Water Sampling}

Eight (8) well and pipe-borne water samples each was randomly collected from different houses in Ajilosun Area, Ado-Ekiti following 
standard procedure. Ajilosun area is located 7.62 latitude and 5.22 longitudes. Each water sample was collected into $1 \mathrm{~L}$ sterile screw capped bottles and transferred into an ice pack. The samples were taken to the laboratory immediately for analyses.

\subsection{Chlorination of Water samples}

According to the manufacturer's instruction, 0.03 $\mathrm{g}$ of water guard was weighed and poured into $500 \mathrm{~mL}$ of each water sample in different testtubes and mixed together properly. Then, exposure time was varied as follows: $30 \mathrm{sec}, 60$ sec, 90 sec.120 sec, $150 \mathrm{sec}$ and 180 sec.

\subsection{Enumeration of Bacterial Load of both Raw and Chlorinated Water Samples}

Each of the water samples was serially diluted to dilution $10^{-3}$ after which $1 \mathrm{ml}$ of $10^{-3}$ was used to inoculate molten Nutrient agar plates using standard pour plates technique. Then incubated at $37{ }^{\circ} \mathrm{C}$ for $24 \mathrm{~h}$. Thereafter, colonies were counted using colony counter.

\subsection{Isolation and Identification of Bacteria from Chlorinated Water Samples}

From each of chlorinated water samples, $1 \mathrm{ml}$ was aseptically withdrawn with a sterile syringe and were transferred onto Nutrient MacConkey and Eosin Methylene Blue (EMB) agar plates, using standard pour plate method. The plates were incubated at $37{ }^{\circ} \mathrm{C}$ for $24 \mathrm{~h}$. After which, colonies were isolated, sub-cultured and identified biochemically.

\subsection{Antibiotic Sensitivity Testing}

The Kirby-Bauer disk diffusion method was used to determine the antibiotic susceptibility profiles of the bacterial isolates from chlorinated water. Antibiotics multidisc used consisted of Tetracycline $(10 \mu g)$, Cotrimoxazole $(25 \mu g)$, Gentamicin (10 $\mu \mathrm{g})$, Cefuroxime (30 $\mu \mathrm{g})$, Chloramphenicol $(10 \mu \mathrm{g})$, Ceftriaxone $(30 \mu \mathrm{g})$, Cefotaxime $(30 \mu g)$, Ciprofloxacin (5 $\mu g)$, Amikacin (30 $\mu \mathrm{g})$, Vancomycin (30 $\mu \mathrm{g})$, Ceftazodime (30 $\mu \mathrm{g}), \quad$ Menopenem $(30 \mu \mathrm{g})$.

\subsection{Molecular Detections of Stress Gene, RpoN, RpoS and KatF Genes from Multiple Antibiotic-Resistant (MAR) Bacterial Isolates from Chlorinated Water Samples}

\subsubsection{DNA extraction}

Identified bacterial Isolates from chlorinated which showed multiple antibiotic resistance were selected for the detection of stress genes. DNA of each bacteria was extracted using the protocol stated by Kam [13]. Briefly, Single colonies grown on medium were transferred to $1.5 \mathrm{ml}$ of liquid medium and cultures were grown on a shaker for $48 \mathrm{~h}$ at $28{ }^{\circ} \mathrm{C}$. After this period, cultures were centrifuged at $4600 \mathrm{~g}$ for $5 \mathrm{~min}$. The resulting pellets were resuspended in $520 \mu \mathrm{l}$ of TE buffer (10 mMTris- $\mathrm{HCl}, 1 \mathrm{mM}$ EDTA, $\mathrm{pH}$ 8.0). Fifteen microliters of $20 \%$ SDS and $3 \mu$ of Proteinase $\mathrm{K}(20 \mathrm{mg} / \mathrm{ml})$ were then added. The mixture was incubated for 1 hour at $37^{\circ} \mathrm{C}$, then $100 \mu \mathrm{l}$ of $5 \mathrm{M} \mathrm{NaCl}$ and $80 \mu \mathrm{l}$ of a $10 \%$ CTAB solution in $0.7 \mathrm{M} \mathrm{NaCl}$ were added and vortexed. The suspension was incubated for $10 \mathrm{~min}$ at 65 ${ }^{\circ} \mathrm{C}$ and kept on ice for $15 \mathrm{~min}$. An equal volume of chloroform: isoamyl alcohol (24:1) was added, followed by incubation on ice for $5 \mathrm{~min}$ and centrifugation at $7200 \mathrm{~g}$ for $20 \mathrm{~min}$. The aqueous phase was then transferred to a new tube and isopropanol (1: 0.6) was added and DNA precipitated at $-20{ }^{\circ} \mathrm{C}$ for $16 \mathrm{~h}$. DNA was collected by centrifugation at $13000 \mathrm{~g}$ for $10 \mathrm{~min}$, washed with $500 \mu \mathrm{l}$ of $70 \%$ ethanol, air-dried at room temperature for approximately three hours and finally dissolved in $50 \mu \mathrm{l}$ of TE buffer.

\subsubsection{Molecular analysis of RpoS, RpoN and KatF genes via PCR}

Molecular investigation of RpoS, RpoN and KatF genes in bacteria isolates was by simple PCR on the extracted DNA using RpoS, RpoN and KatF genes coding regions specific primers. Primer sequences for each gene are stated in Table 1. Reaction cocktail used for all PCR per primer set included (Reagent Volume $\mu \mathrm{l}$ ) - 5X PCR SYBR green buffer (2.5), $\mathrm{MgCl}_{2}$ (0.75), 10 pM DNTP (0.25), $10 \mathrm{pM}$ of forward and reverse primers, $8000 \mathrm{U}$ of taq DNA polymerase $(0.06)$ and made up to 10.5 with sterile distilled water to which $2 \mu \mathrm{l}$ template was added. Reaction profile for each RpoS, RpoN and KatF gene identification included an initial denaturing for $5 \mathrm{~min}$ at $94^{\circ} \mathrm{C}$, then 35 cycles of $94^{\circ} \mathrm{C}$ for $30 \mathrm{~s}, 59^{\circ} \mathrm{C}$ for $45 \mathrm{~s}$ and $72{ }^{\circ} \mathrm{C}$ for $60 \mathrm{~s}$ and terminate at $72{ }^{\circ} \mathrm{C}$ for 10 min. PCR was carried out in a GeneAmp 9700 
PCR System Thermal cycler (Applied Biosystem Inc., USA) using the appropriate profile as designed for each primer pair as previously.

\subsubsection{Integrity}

The integrity of the amplified fragments was checked on a $1.5 \%$ Agarose gel ran to confirm amplification. The buffer (1XTAE buffer) was prepared and subsequently used to prepare 1.5 $\%$ agarose gel. The suspension was boiled in a microwave for 5 minutes. The molten agarose was allowed to cool to $60{ }^{\circ} \mathrm{C}$ and stained with 3 $\mu \mathrm{l}$ of $0.5 \mathrm{~g} / \mathrm{ml}$ ethidium bromide (which absorbs invisible UV light and transmits the energy as visible orange light). A comb was inserted into the slots of the casting tray and the molten agarose was poured into the tray. The gel was allowed to solidify for 20 minutes to form the wells. The 1XTAE buffer was poured into the gel tank to barely submerge the gel. Two microliter $(2 \mu \mathrm{l})$ of $10 \mathrm{X}$ blue gel loading dye (which gives colour and density to the samples to make it easy to load into the wells and monitor the progress of the gel) was added to $4 \mu \mathrm{l}$ of each PCR product and loaded into the wells after the 100 bp DNA ladder was loaded into well 1 . The gel was electrophoresed at $120 \mathrm{~V}$ for 45 minutes visualized by ultraviolet trans-illumination and photographed. The sizes of the PCR products were estimated by comparison with the mobility of a $100 \mathrm{bp}$ molecular weight ladder that was ran alongside experimental samples in the gel.

\section{RESULTS AND DISCUSSION}

The result in Table 2 shows the mean total viable bacterial count of the raw and chlorinated water samples from different homes in Ajilosun, AdoEkiti. The mean count of the raw water samples was considerably higher than chlorinated water samples. Also, a gradual reduction in coliform count with increase exposure rate was also observed in the water samples exposed to chlorine compound (water guard). Table 3 reveals that total number of bacterial isolates recovered from chlorinated water samples. Pipeborne water samples had more isolates (60.71 $\%)$ than the well water samples. The different identified bacterial isolates recovered from chlorinated water samples included Enterobacter aerogenes (7.14\%), Proteus vulgaris (10.71\%), Escherichia coli (25\%), Bacillus cereus (32.14 $\%)$ Bacillus licheniformis (14.29 \%) and Staphylococcus aureus (10.70 \%) Table 4. Fig. 1 depicts the percentage resistance profile of each identified bacteria from chlorinated water to different antibiotics. And it was observed that the bacterial isolates demonstrated varying resistance pattern to the different antibiotics. Among the antibiotics, Gentamicin (GEN) and Amikacin (AMK) were active against all the bacteria isolates while Ciprofloxacin (CIP) showed considerable activity against all the isolates except one E. coli and S. aureus.

Table 5 shows the genomic purity of DNA isolated from the MAR bacteria from chlorinated water samples. The absorbance quotient values ranged from 1.92 to 2.32 . The integrity of genomic DNA samples were confirmed on $1.5 \%$ agarose gel by electrophoresis (Plate 1).

The result shown on plate 2 depicts the PCR products amplified from the selected bacteria isolates with band size of approximately $300 \mathrm{bp}$. A positive amplification indicates the presence of RpoS gene. Results indicates that Proteus vulgaris in lane 3 and $E$. coli $A$ and $B$ in lane 6 and 7 respectively were positive for the presence of RpoS genes (Plate 2). Plate 3 shows that only bacterial isolates, $E$. coli $(A)$ and $(B)$, on lane 6 and 7 were positive for $R p o N$ gene with band size of approximately 730 bp while isolates, Bacillus licheniformis (A), (B), and $E$. coli (B) in lane 4, 5 and 7 were positive for KatF with size of approximately 500 bp (Plate 4).

Table 1. Primers used in the study

\begin{tabular}{|c|c|c|c|}
\hline Gene & Primer & Primer sequence & Reference \\
\hline Rpos & RpoS-F & CCGTTATGGCAATCGTGGTCT & [14] \\
\hline & RpoS-R & TGACGTCATCAACTGGCTTATCC & \\
\hline $\operatorname{RpoN}$ & $\begin{array}{l}R p o N-F \\
R p o N-R\end{array}$ & $\begin{array}{l}\text { GTCAGTAGGAGGCTGAACATGA } \\
\text { CGCATTAAAGTGCGGAAGTC }\end{array}$ & [15] \\
\hline KatF & $\begin{array}{l}\text { KatF-F } \\
\text { KatF-R }\end{array}$ & $\begin{array}{l}\text { TAACTTGCGTCTGGTGGTAAA } \\
\text { CGTCATCTTGCGTGGTATCT }\end{array}$ & Self \\
\hline
\end{tabular}


Olowe and Adelegan; ARRB, 36(4): 120-131, 2021; Article no.ARRB.67526

Table 2. The mean total viable bacteria count (TVBC) of raw and chlorinated water samples collected from different homes in Ajilosun, Ado-Ekiti, Ekiti State

\begin{tabular}{|c|c|c|c|c|c|c|c|c|}
\hline $\begin{array}{l}\text { Water } \\
\text { sample (n) }\end{array}$ & $\begin{array}{l}\text { Mean TVBC } \pm \text { SD } \\
\left(\log _{10} \mathrm{cfu} / \mathrm{ml}\right)\end{array}$ & 30 secs & 60 secs & 90 secs & 120 secs & 150 secs & 180 secs & $\begin{array}{l}\% \\
\text { Reduction } \\
\text { after } 180 \\
\text { secs }\end{array}$ \\
\hline & $\begin{array}{l}\text { Raw water } \\
\text { samples }\end{array}$ & \multicolumn{7}{|c|}{ Mean TVBC \pm SD $\left(\log _{10} \mathrm{cfu} / \mathrm{ml}\right)$ Chlorinated water samples } \\
\hline Well (8) & $4.1642 \pm 0.64$ & $3.4545 \pm 0.28$ & $3.2342 \pm 0.41$ & $3.3914 \pm 0.47$ & $3.3274 \pm 0.36$ & $3.2494 \pm 0.47$ & $3.1842 \pm 0.56$ & $24 \%$ \\
\hline $\begin{array}{l}\text { Pipe-borne } \\
\text { water (8) }\end{array}$ & $3.7556 \pm 0.55$ & $2.460 \pm 0.37$ & $1.7518 \pm 1.24$ & $1.8257 \pm 1.31$ & $1.8521 \pm 1.32$ & $0.9261 \pm 1.31$ & $1.7934 \pm 1.27$ & $52 \%$ \\
\hline
\end{tabular}


Table 3. Bacterial isolates recovered from chlorinated water samples

\begin{tabular}{ll}
\hline Water samples $(\mathbf{n})$ & Total Number of isolates recovered $(\%)$ \\
\hline Wells $(8)$ & $11(39.29)$ \\
Pipe-borne $(8)$ & $17(60.71)$ \\
Total & $28(100)$ \\
\hline
\end{tabular}

Table 4. Percentage occurrence of identified bacterial isolates from chlorinated water Samples from Ajilosun, ado- ekiti, ekiti- state

\begin{tabular}{|c|c|c|c|}
\hline Bacteria isolates & Pipe-borne water N (\% & Well water N (\%) & Total N (\%) \\
\hline Enterobacter aerogenes & $0(0)$ & $2(18.18)$ & $2(7.14)$ \\
\hline Proteus vulgaris & $1(5.88)$ & $2(18.18)$ & $3(10.71)$ \\
\hline Escherichia coli & $4(23.53)$ & $3(27.27)$ & $7(25.0)$ \\
\hline Bacillus cereus & $8(47.06)$ & $1(9.09)$ & $9(32.14)$ \\
\hline Bacillus licheniformis & $3(17.65)$ & $1(9.09)$ & $4(14.29)$ \\
\hline Staphylococcus aureus & $1(5.88)$ & $2(18.18)$ & $3(10.71)$ \\
\hline Total & $17(100)$ & $11(100)$ & $28(100)$ \\
\hline
\end{tabular}

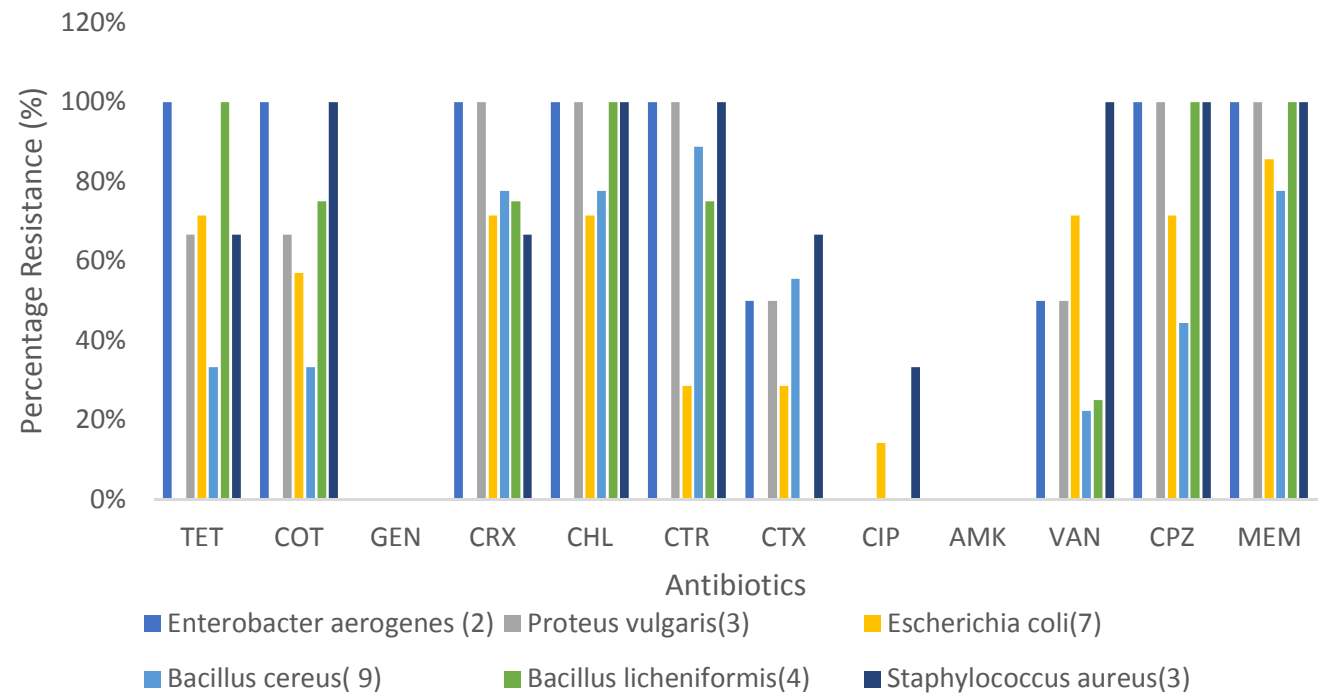

Fig. 1. Percentage resistance pattern of bacteria isolates from chlorinated water samples KEY: TET- Tetracycline $(10 \mu \mathrm{g})$, COT-Cotrimoxazole $(25 \mu \mathrm{g})$, GEN- Gentamicin $(10 \mu \mathrm{g})$, CRX-Cefuroxime (30 $\mu \mathrm{g})$, CHL-Chloramphenicol (10 $\mu \mathrm{g})$, CTR- Ceftriaxone (30 $\mu \mathrm{g})$, CTX- Cefotaxime (30 $\mu \mathrm{g})$, CIP- Ciprofloxacin (5 $\mu \mathrm{g})$, AMK-Amikacin (30 $\mu \mathrm{g}$ ), VAN-Vancomycin (30 $\mu \mathrm{g})$, CPZ-Ceftazodime (30 $\mu \mathrm{g})$, MEM-Menopenem (30 $\mu \mathrm{g})$.

Table 5. Integrity of DNA extracted from bacteria samples

\begin{tabular}{llllll}
\hline Sample ID & Nucleic Acid & Unit & A260 (Abs) & A280 (Abs) & $\mathbf{2 6 0 / 2 8 0}$ \\
\hline $\mathrm{sdH} 2 \mathrm{O}$ & 0.3 & $\mathrm{ng} / \mu \mathrm{l}$ & 0.006 & 0.017 & 0.34 \\
1 & 955.5 & $\mathrm{ng} / \mu \mathrm{l}$ & 0.111 & 0.049 & 2.28 \\
2 & 715 & $\mathrm{ng} / \mu \mathrm{l}$ & 0.3 & 0.154 & 1.95 \\
3 & 949.5 & $\mathrm{ng} / \mu \mathrm{l}$ & 0.189 & 0.089 & 2.12 \\
4 & 346.7 & $\mathrm{ng} / \mu \mathrm{l}$ & 0.141 & 0.061 & 2.32 \\
5 & 510.6 & $\mathrm{ng} / \mu \mathrm{l}$ & 0.211 & 0.096 & 2.2 \\
6 & 765.8 & $\mathrm{ng} / \mu \mathrm{l}$ & 0.584 & 0.304 & 1.92 \\
7 & 1237.2 & $\mathrm{ng} / \mu \mathrm{l}$ & 0.145 & 0.064 & 2.27 \\
\hline
\end{tabular}




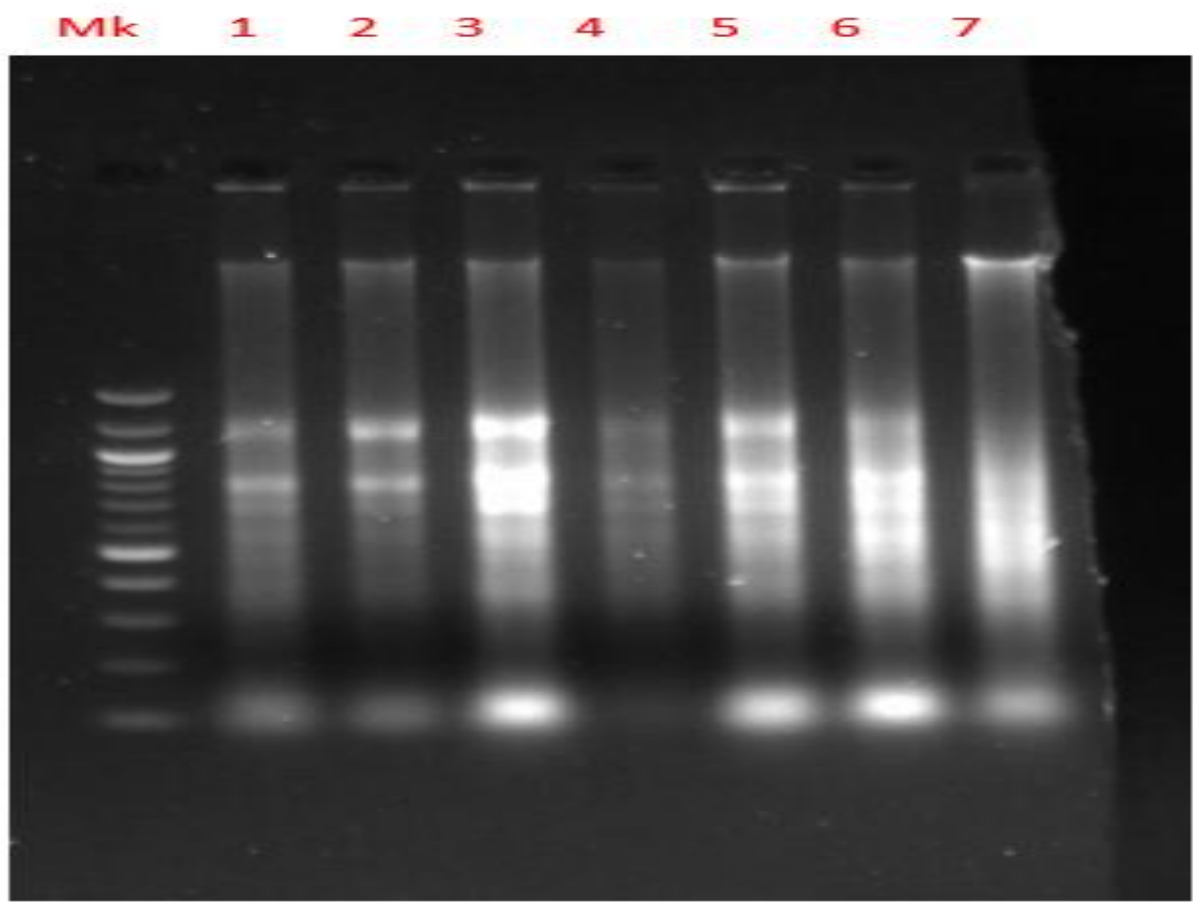

Plate 1. Nanodrop quantification showing the DNA quantity extracted from each bacteria isolates: Mk- marker, Lane 1- Bacillus cereus (A), Lane 2- Bacillus cereus (B), Lane 3- Proteus vulgaris, Lane 4- Bacillus licheniformis (A), Lane 5- Bacillus licheniformis (B), Lane 6 E. coli (A) and Lane 7- E. coli (B)

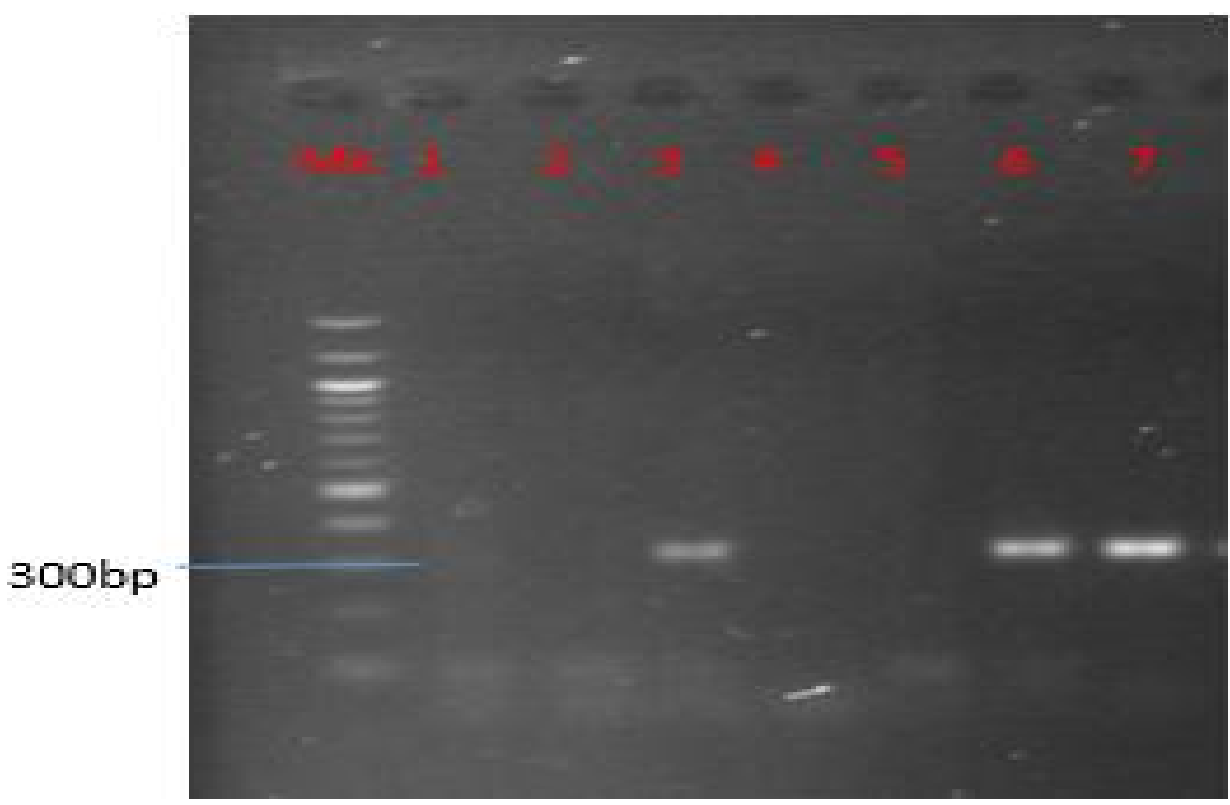

Plate 2. Agarose Gel electrophoresis of the RpoS gene (300 bp)

Mk- marker, Lane 1- Bacillus cereus (A), Lane 2-Bacillus cereus (B), Lane 3- Proteus vulgaris, Lane 4- Bacillus licheniformis (A), Lane 5- Bacillus licheniformis (B), Lane 6 E. coli (A) and Lane 7- E. coli (B) 


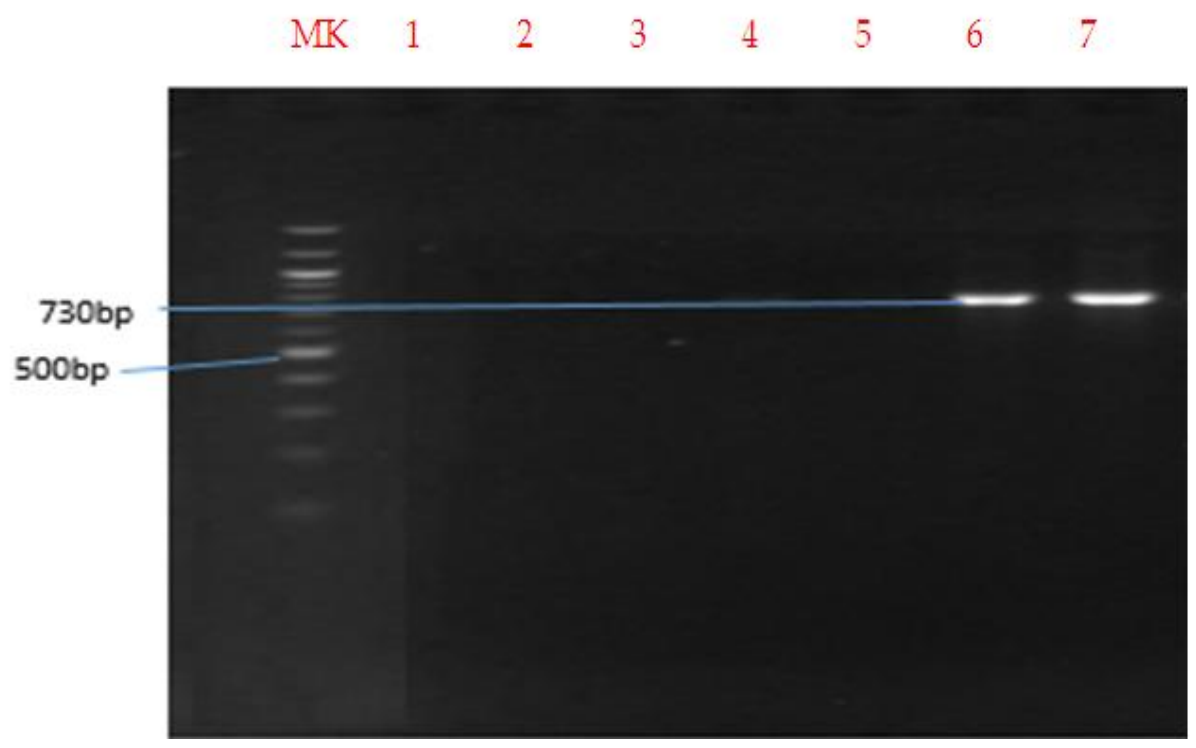

Plate 3. Agarose gel electrophoresis of the RpoN gene (730 bp)

Mk- marker, Lane 1- Bacillus cereus (A), Lane 2-Bacillus cereus (B), Lane 3- Proteus vulgaris, Lane 4- Bacillus licheniformis (A), Lane 5- Bacillus licheniformis (B), Lane 6 E. coli (A) and Lane 7- E. coli (B)

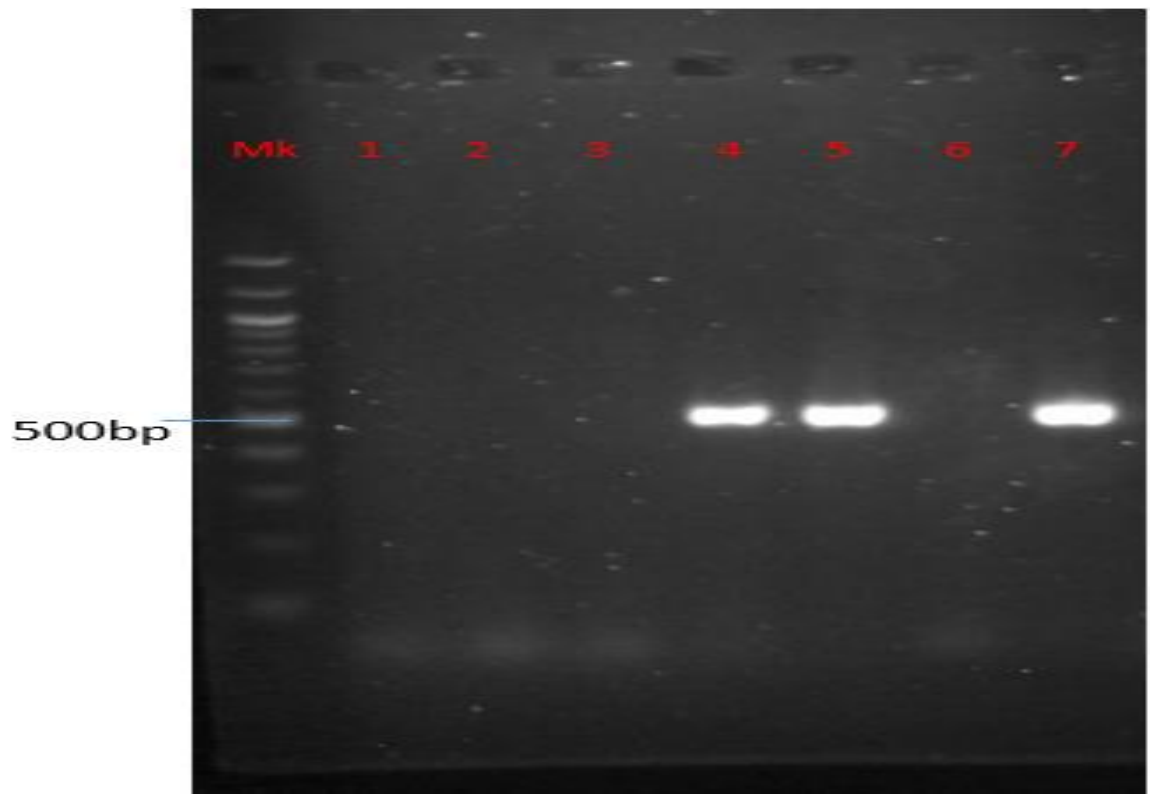

Plate 4. Agarose gel electrophoresis of the KatF gene (500 bp)

Mk- marker, Lane 1- Bacillus cereus (A), Lane 2-Bacillus cereus (B), Lane 3- Proteus vulgaris, Lane 4- Bacillus licheniformis (A), Lane 5- Bacillus licheniformis (B), Lane 6 E. coli (A) and Lane 7- E. coli

The microbiological quality assessment of the different water samples before and after chlorination was essential for determining the presence or absence of organisms that might constitute health hazards from domestic use of the water. The total viable bacterial counts
(TVBC) for all the samples were generally high, exceeding the limit of $2.0 \mathrm{log} \mathrm{cfu} / \mathrm{ml}$ which was the standard limit for heterotrophic count of drinking water [16]. This is in agreement with findings from study by Agwaranze, et al. [17] who also reported a considerable high TVBC from 
different well water samples collected in Wukari, Taraba State, Nigeria. The high TVBC observed in the well water samples indicated the presence of high organic matter and related nutrient sources. The likely primary source of bacterial contamination might include the surface run-off, natural soil/plants bacteria and improper management activities of the inhabitants like washing, refuse disposal, faecal droppings, dipping of different fetchers inside the wells which were observed during onsite observation at Ajilosun, Ado-Ekiti. It was also observed that chlorination of the water samples according to manufacturer's instruction at exposure rate of 180 secs was effective in reducing the TVBC of the water sample. The TVBC level at 180 secs for the well water samples was not safe for consumption. Though Water Guard has 100\% efficacious against pathogens, the inefficacy noticed on well water samples can be affected by temperature, $\mathrm{pH}$ and organic matter concentration among other factors [18]. While the TVBC for pipe-borne water was reduced to safer level for consumption as it was $<2.0 \mathrm{log} \mathrm{cfu} / \mathrm{ml}$. Tersagh, et al. [4] advocated for the use of water guard in various homes to disinfect their water before use as their study also confirmed a drastic reduction in TVBC after chlorination.

Yoltana and Masitauri [18] reported $100 \%$ disinfection microbial disinfection of water samples with water guard after 5 minutes contact time. This is contrary to the results from this study as some microorganisms were isolated even after treatment with water guard following the manufacturer's instruction. The various groups of microorganisms isolated and identified during this study have one pathogenic effect or the other and their presence is indicative of water contamination from some domestic sources. Hence unfit for human consumption. These microorganisms; Enterobacter aerogenes, Proteus vulgaris, Escherichia coli, Bacillus cereus, Bacillus licheniformis and Staphylococcus aureus; isolated from chlorinated water samples are said to be chlorine-resistant or chlorine-tolerant. This corroborates the results obtained from study by Tersagh, et al. [4]. They recovered Escherichia coli (49.27\%), Klebsiella spp (16.79\%), Diphtheroid spp (6.57\%), Staphylococcus aureus (27.37\%) after treatment of water samples with water guard.

This study also revealed that chlorine-resistant bacterial isolates were at the same time resistant to majority of the antibiotics used during antibiotic sensitivity testing. Theoretically, chlorination of water should help diminish, or even eliminate, ARB and ARG. However, it has been reported that the ARG level is higher in chlorinated water than that in pre-disinfected water $[5,12,19-21]$. This might probably be as a result of the release of extracellular ARG released from killed bacteria during chlorination process [22]. Thus, promoting the uptake of released ARG and genetic transformation across bacteria. Furthermore, culturable chlorine-injured bacteria may play roles in this process. Culturable chlorine-injured bacteria are viable but physiologically unhealthy populations tolerant to chlorine [21]. These bacteria may account for as much as $90 \%$ of all indicator bacteria present after disinfection $[23,21]$.

The co-occurrence of chlorine and antibiotic resistance of the bacterial isolates in this study could be associated by sharing of function (chlorine and antibiotic resistance expressed by the same gene, commonly indicated as crossresistance), by co-regulation of their gene expression and by the co-localization of resistance genes (chlorine resistance and AR genes physically located on the same mobile element, commonly indicated as co-resistance) [24]. In addition, Krige [25] reported that crossresistance may be involved in the antibiotic resistance promotion, since chlorination can decrease bacterial membrane permeability and inhibit molecular transport which results in antibiotic resistance.

This study reports the presence of stressed genes, RpoS, RpoN and KatF in some of the ARB investigated which could probably be as a result of the afore-mentioned factors. The gene RpoS (RNA polymerase, sigma S) encodes the sigma factor sigma-38 ( $\sigma 38$, or RpoS), a $37.8 \mathrm{kD}$ protein in Escherichia coli [26]. RpoS is a stationary phase/stress sigma factor of Escherichia coli which regulates a large cohort of genes important for the cell to deal with suboptimal conditions. Its level increases quickly in the cell in response to many stresses like UV radiation, acid, temperature, osmotic shock, oxidative stress and nutrient deprivation [27-28] and returns to low levels when growth resumes. Increased RpoS results from increased translation and decreased RpoS degradation [29]. RpoS as a central regulator of the general stress response, operates in both a retroactive and a proactive manner: it not only allows the cell to survive environmental challenges, but it also prepares the cell for subsequent stresses (crossprotection) [30]. 
The gene RpoN (RNA polymerase, nitrogenlimitation $\mathrm{N}$ ) encodes the sigma factor sigma-54 ( $\sigma 54$, sigma $\mathrm{N}$, or $\mathrm{RpoN}$ ), a protein in Escherichia coli and other species of bacteria. It was originally identified as a regulator of genes involved in nitrogen metabolism and assimilation under nitrogen limiting conditions [31]. RpoN ( $\sigma 54)$ is a conserved regulator in the bacterial kingdom that plays essential roles in regulating metabolism, motility and virulence of different species [32-33]. While the protein encoded by KatF (putative sigma factor) gene regulates several other genes important for survival during dormancy. Variants of KatF protein may selectively initiate transcription on some (but not all) promoters in response to different adverse environmental conditions or stage of growth of cells [34]. This gene identified in some of the ARB investigated enhance long-term survival in nutrient-deficient medium and have a diverse group of functions including protection against DNA damage, the determination of morphological changes, the mediation of virulence, osmoprotection, and thermotolerance.

\section{CONCLUSION}

The study reveals the importance of chlorination in reducing microbial load of drinking water. However, it also pinpoints chlorination impact in contributing to increasing incidences of resistance of bacteria to stressors (water treatment methods) in water environment by the detection of stress genes in antibiotic-resistant bacteria recovered from chlorinated water. Hence, underscoring the paradoxical role of chlorine or chlorine compound in water treatment.

\section{ACKNOWLEDGEMENTS}

I thank Olaniyan Oluwaleke and Blessing Tolulope for their technical assistance in the course of the study. Also, I appreciate the Management of Federal Polytechnic, Ado-Ekiti, Ekiti State for their support to carry out the study in their research laboratory.

\section{COMPETING INTERESTS}

Authors have declared that no competing interests exist.

\section{REFERENCES}

1. Ateba CN, Tabi NM, Fri J, Bissong MEA, Bezuidenhout CC. Occurrence of
Antibiotic-Resistant Bacteria and Genes in Two Drinking Water Treatment and Distribution Systems in the North-West Province of South Africa. Antibiotics. 2020;9(11):745.

2. Nontongana $\mathrm{N}$, Sibanda $\mathrm{T}$, Ngwenya $\mathrm{E}$, Okoh Al. Prevalence and antibiogram profiling of Escherichia coli pathotypes isolated from the Kat River and the Fort Beaufort abstraction water. International journal of environmental research and public health. 2014;11(8):8213-8227.

3. Furukawa T, Jikumaru A, Ueno T, Sei K. Inactivation effect of antibiotic-resistant gene using chlorine disinfection. Water. 2017;9(7):547.

4. Tersagh I, Dooshima N, Peter OJ. Efficacy of water guard disinfectant as a domestic stored water treatment method in Makurdi metropolis. Research Journal of Environmental Science. 2015;9(8):364.

5. Xi C, Zhang Y, Marrs CF, Ye W, Simon C, Foxman B, Nriagu J. Prevalence of antibiotic resistance in drinking water treatment and distribution systems. Applied and environmental microbiology. 2009;75(17):5714-5718.

6. Di Cesare A, Eckert EM, Teruggi A, Fontaneto D, Bertoni R, Callieri C, Corno G. Constitutive presence of antibiotic resistance genes within the bacterial community of a large subalpine lake. Molecular Ecology. 2015;24(15):38883900.

7. Chen CW, Hsu CY, Lai SM, Syu WJ, Wang TY, Lai PS. Metal nanobullets for multidrug resistant bacteria and biofilms. Advanced drug delivery reviews. 2014;78:88-104.

8. Khan S, Beattie TK, Knapp CW. Relationship between antibiotic-and disinfectant-resistance profiles in bacteria harvested from tap water. Chemosphere. 2016;152:132-141.

9. Templeton MR, Oddy F, Leung WK, Rogers M. Chlorine and UV disinfection of ampicillin-resistant and trimethoprimresistant Escherichia coli. Canadian Journal of Civil Engineering. 2009;36(5):889-894.

10. Huang JJ, Hu HY, Wu YH, Wei B, Lu Y. Effect of chlorination and ultraviolet disinfection on tetA-mediated tetracycline resistance of Escherichia coli. Chemosphere. 2013;90(8):2247-2253.

11. Jia S, Shi $P$, Hu Q, Li B, Zhang T, Zhang $X X$. Bacterial community shift drives 
antibiotic resistance promotion during drinking water chlorination. Environmental science \& technology. 2015;49(20):1227112279.

12. Shi $\mathrm{P}$, Jia $\mathrm{S}$, Zhang $\mathrm{XX}$, Zhang $\mathrm{T}$, Cheng $S$, Li A. Metagenomic insights into chlorination effects on microbial antibiotic resistance in drinking water. Water research. 2013;47(1):111-120.

13. Kam Y, Rubinstein A, Nissan A, Halle D, Yavin $E$. Detection of endogenous K-ras mRNA in living cells at a single base resolution by a PNA molecular beacon. Molecular pharmaceutics. 2012;9(3):685693.

14. Sheldon $\mathrm{FH}$, Oliveros $\mathrm{CH}$, Taylor SS, McKay B, Lim HC, Rahman MA, et al. Molecular phylogeny and insular biogeography of the lowland tailorbirds of Southeast Asia (Cisticolidae: Orthotomus). Molecular Phylogenetics and Evolution. 2012;65(1):54-63.

15. Terui $Y$, Higashi $K$, Taniguchi $S$, Shigemasa A, Nishimura K, Yamamoto $\mathrm{K}$,et al. Enhancement of the synthesis of $\mathrm{RpoN}$, Cra, and $\mathrm{H}-\mathrm{NS}$ by polyamines at the level of translation in Escherichia coli cultured with glucose and glutamate. Journal of bacteriology. 2007;189(6):23592368.

16. Environmental Protection Agency (EPA), Safe Drinking Water Act Amendment; 2002. [Online].

Available:http://www.epa.gov/safe/mcl/Htm I.

17. Agwaranze DI, Ogodo AC, Nwaneri CB, Agyo P. Bacteriological examination of well water in Wukari, Nigeria. International Journal of Scientific Research in Environmental Sciences. 2017;5(2):00420046.

18. Yoltana $L$ Masitauri D. Potential use of Waterguard as a disinfectant for domestic water use. Tanzania Journal of Engineering and Technology. 2008;2(2):61-69.

19. Zheng DW, Chen JL, Zhu JY, Rong L, Li B, Lei $Q$, et al. Highly integrated nanoplatform for breaking the barrier between chemotherapy and immunotherapy. Nano letters. 2016;16(7):4341-4347.

20. Liu SS, Qu HM, Yang D, Hu H, Liu WL, Qiu ZG, et al. Chlorine disinfection increases both intracellular and extracellular antibiotic resistance genes in a full-scale wastewater treatment plant. Water research. 2018;136:131-136.
21. Jin M, Liu L, Wang DN, Yang D, Liu WI, Yin J, et al. Chlorine disinfection promotes the exchange of antibiotic resistance genes across bacterial genera by natural transformation. The ISME journal. 2020;14(7):1847-1856.

22. Dodd MC. Potential impacts of disinfection processes on elimination and deactivation of antibiotic resistance genes during water and wastewater treatment. Journal of Environmental 2012;14(7):1754-1771.

23. Bissonnette G, Jezeski J, McFeters G, Stuart D. Influence of environmental stress on enumeration of indicator bacteria from natural waters. Applied Microbiology. 1975;29(2):186-194.

24. Di Cesare A, Eckert E, Corno G. Coselection of antibiotic and heavy metal resistance in freshwater bacteria. Journal of Limnology. 2016;75.

25. Krige M. Molecular investigation of the chlorine and antibiotic resistance mechanisms of Escherichia coli isolated from natural water sources in the Western Cape," Stellenbosch: University of Stellenbosch; 2009.

26. Frederix M, Downie JA. Quorum sensing: regulating the regulators. Advances in microbial physiology. 2011;58:23-80.

27. Durfee T, Nelson R, Baldwin S, Plunkett G, Burland V, Mau B, et al. The complete genome sequence of Escherichia coli DH10B: insights into the biology of a laboratory workhorse. Journal of bacteriology. 2008;190(7):2597-2606.

28. Klauck E, Typas A, Hengge R. The oS subunit of RNA polymerase as a signal integrator and network master regulator in the general stress response in Escherichia coli. Science progress. 2007;90(2-3):103127.

29. Battesti A, Majdalani N, Gottesman S. Stress sigma factor RpoS degradation and translation are sensitive to the state of central metabolism. Proceedings of the National Academy of Sciences. 2015;112(16):5159-5164.

30. Hengge-Aronis R. Signal transduction and regulatory mechanisms involved in control of the $\sigma S$ (RpoS) subunit of RNA polymerase. Microbiology and Molecular Biology Reviews. 2002;66(3):373-395.

31. Cai Z, Liu Y, Chen Y, Yam JKH, Chew SC, Chua SL, et al. RpoN regulates virulence factors of Pseudomonas aeruginosa via modulating the PqsR quorum sensing 
regulator. International journal of molecular sciences. 2015;16(12):28311-28319.

32. Reitzer L. Nitrogen assimilation and global regulation in Escherichia coli. Annual Reviews in Microbiology. 2003;57(1):155176.

33. Wolfe AJ, Millikan DS, Campbell JM, Visick KL. Vibrio fischeri o54 controls motility, biofilm formation, luminescence, and colonization. Applied and Environmental Microbiology. 2004;70(4):2520-2524.

34. Ivanova A, Renshaw M, Guntaka RV, Eisenstark A. DNA base sequence variability in katF (putative sigma factor) gene of Escherichia coli. Nucleic acids research. 1992;20(20):5479.

(c) 2021 Olowe and Adelegan; This is an Open Access article distributed under the terms of the Creative Commons Attribution License (http://creativecommons.org/licenses/by/4.0), which permits unrestricted use, distribution, and reproduction in any medium, provided the original work is properly cited.

Peer-review history:

The peer review history for this paper can be accessed here: http://www.sdiarticle4.com/review-history/67526 